\title{
Novel Pathogenic Mutation Mapping of ASPM Gene in Consanguineous Pakistani Families with Primary Microcephaly
}

\author{
Novo mapeamento de mutações patogênicas do gene ASPM em famílias consanguíneas \\ com microcefalia primária do Paquistão
}

T. Batool ${ }^{\mathrm{a}}$ (D), S. Irshad ${ }^{*}$ (ib) and K. Mahmood ${ }^{\mathrm{b}}$ (1)

aUniversity of the Punjab, School of Biochemistry and Biotechnology - SBB, Lahore, Pakistan

bUniversity of the Punjab, Department of Technology Education - IER, Lahore, Pakistan

\begin{abstract}
Autosomal recessive primary microcephaly (MCPH) is a neurodevelopmental disorder characterized by a congenitally reduced head circumference ( -3 to $-5 \mathrm{SD}$ ) and non-progressive intellectual disability. The objective of the study was to evaluate pathogenic mutations in the ASPM gene to understand etiology and molecular mechanism of primary microcephaly. Blood samples were collected from various families across different remote areas of Pakistan from February 2017 to May 2019 who were identified to be affected with primary microcephaly. DNA extraction was performed using the salting-out method; the quality and quantity of DNA were evaluated using spectrophotometry and $1 \%$ agarose gel electrophoresis, respectively in University of the Punjab. Mutation analysis was performed by whole exome sequencing from the Cologne Center for Genomics, University of Cologne. Sanger sequencing was done in University of the Punjab to confirm the pathogenic nature of mutation. A novel 4-bp deletion mutation c.3877_3880delGAGA was detected in exon 17 of the ASPM gene in two primary microcephaly affected families (A and $B$ ), which resulted in a frame shift mutation in the gene followed by truncated protein synthesis (p.Glu1293Lysfs*10), as well as the loss of the calmodulin-binding IQ domain and the Armadillo-like domain in the ASPM protein. Using the in-silico tools Mutation Taster, PROVEAN, and PolyPhen, the pathogenic effect of this novel mutation was tested; it was predicted to be "disease causing," with high pathogenicity scores. One previously reported mutation in exon 24 (c.9730C $>$ T) of the ASPM gene resulting in protein truncation (p.Arg3244*) was also observed in family C. Mutations in the ASPM gene are the most common cause of MCPH in most cases. Therefore, enrolling additional affected families from remote areas of Pakistan would help in identifying or mapping novel mutations in the ASPM gene of primary microcephaly.
\end{abstract}

Keywords: Primary microcephaly, ASPM gene, Whole-exome sequencing, Novel mutation.

\begin{abstract}
Resumo
Microcefalia primária autossômica recessiva (MCPH) é um distúrbio do neurodesenvolvimento caracterizado por uma redução congênita do perímetro cefálico (-3 a -5 DP) e deficiência intelectual não progressiva. 0 objetivo do estudo foi avaliar mutações patogênicas no gene ASPM a fim de compreender a etiologia e o mecanismo molecular da microcefalia primária. Amostras de sangue foram coletadas de várias famílias em diferentes áreas remotas do Paquistão de fevereiro de 2017 a maio de 2019, que foram identificadas como afetadas com microcefalia primária. A extração do DNA foi realizada pelo método salting-out; a qualidade e a quantidade de DNA foram avaliadas por espectrofotometria e eletroforese em gel de agarose a 1\%, respectivamente, na Universidade de Punjab. A análise de mutação foi realizada por sequenciamento completo do exoma do Cologne Center for Genomics, University of Cologne. O sequenciamento de Sanger foi feito na Universidade do Punjab para confirmar a natureza patogênica da mutação. Uma nova mutação de deleção de 4 bp c.3877_3880delGAGA foi detectada no exon 17 do gene ASPM em duas famílias afetadas por microcefalia primária (A e B), que resultou em uma mutação de frame shift no gene seguida por síntese de proteína truncada (pGlu1293Lysfs * 10), bem como a perda do domínio IQ de ligação à calmodulina e o domínio do tipo Armadillo na proteína ASPM. Usando as ferramentas in-silico Mutation Taster, PROVEAN e PolyPhen, o efeito patogênico dessa nova mutação foi testado; foi previsto ser "causador de doenças", com altos escores de patogenicidade. Uma mutação relatada anteriormente no exon 24 (c.9730C > T) do gene ASPM, resultando em truncamento de proteína (p.Arg3244*) também foi observada na família C. Mutações no gene ASPM são a causa mais comum de MCPH na maioria dos casos. Portanto, a inscrição de famílias afetadas adicionais de áreas remotas do Paquistão ajudaria a identificar ou mapear novas mutações no gene ASPM da microcefalia primária.
\end{abstract}

Palavras-chave: Microcefalia primária, gene ASPM, sequenciamento de exoma completo, Nova mutação.

*e-mail: saba.sbb@pu.edu.pk

Received: November 28, 2020 - Accepted: January 12, 2021

This is an Open Access article distributed under the terms of the Creative Commons Attribution License, which permits unrestricted use, distribution, and reproduction in any medium, provided the original work is properly cited. 


\section{Introduction}

Autosomal recessive primary microcephaly $(\mathrm{MCPH})$ is a rare, neurodevelopmental defect that invariably leads to smaller brain size and decreased cognitive functions. It is characterized by reduced head circumference ( -3 to $-5 \mathrm{SD}$ ), based on age and sex (Naveed et al., 2018; Wollnik, 2010). $\mathrm{MCPH}$ patients present a variable degree of intellectual disability; typically, a smaller brain size with simplified gyral patterns and pituitary anomalies in the cerebral cortex, as well as a significant decrease in the size of the architecturally normal brain (Woods and Parker, 2013; Thornton and Woods, 2009). Mutations in genes that are involved in brain growth and development (such as proliferation or differentiation of progenitor cells) or cell apoptosis can lead to MCPH (Tischfield et al., 2011; Roberts et al.,2002; Jayaraman et al., 2018).

To date, $25 \mathrm{MCPH}$ loci have been mapped (MCPH1 to $\mathrm{MCPH} 25$ ) and have the following causative genes: Microcephalin, WDR62, CDK5RAP2, CASC5, ASPM, CENPJ, STIL, CEP135, CEP152, ZNF335, PHC1, CDK6, CENPE, SASS6, MFSD2A, ANKLE2, CIT and WDFY3, COPB2, KIF14, NCAPD2, NCAPD3, NCAPH, NUP37 and MAP11. These molecular basis studies clarify our understanding of microcephaly genetic disorder (Perez et al., 2019; Bond et al., 2002). The ASPM gene (MIM 605481) at the MCPH5 locus has 28 exons and spans $62.54 \mathrm{~kb}$ of genomic DNA, with a $10,434 \mathrm{bp}$ long open reading frame (ORF) that encodes a protein 3477 amino acids in length. The ASPM protein has four main regions: a putative $\mathrm{N}$-terminal microtubule-binding domain, a calponin-homology domain $(\mathrm{CH}), 81$ calmodulin-binding IQ repeats, and a C-terminal region. Most IQ motifs are organized into higher order trimer repeats (HOR) containing two 23-amino acid residue units and one 27-amino acid residue unit (Hina et al., 2019; Li et al., 2016).

The incidence of MCPH is relatively high (approximately $1 / 10,000$ ) in regions where consanguineous marriages are common, such as in Pakistan. So far in Pakistani population, ASPM gene mutations are almost $50 \%$ of all MCPH cases reported, including 94 nonsense and missense mutations, 88 small deletion mutations, 16 small insertion mutations, 2 gross deletions, 18 splicing mutations, and 1 mutation of complex rearrangement from a total of 219 pathogenic ASPM gene mutations (HGMD, Professional 2017.4, http:// www.hgmd.org/). The ASPM gene encodes the protein involved in brain development and cell division. It is also important for maintaining neural progenitor cells (early brain cells maintained by the ASPM protein) that ultimately develop into neurons (mature brain cells) (Bibi et al., 2018).

The overall brain size and the total number of neurons are determined by ASPM protein involvement. ASPM protein mutations are likely the probable cause of microcephaly (Bundey, 1997).

Microcephaly is a significant disorder having genotypic and phenotypic heterogeneity. During searching, identification, and blood sampling of microcephaly families, we would be capable to properly council these affected families and their relatives. Well guidance and awareness of this disorder and to avoid marriages within families may eradicate this disorder. With novel mutation analysis may lead to identification of new protein involved in causes of primary microcephaly. Through this project a new molecular spectrum of microcephaly may be opened.

\section{Materials and Methods}

Microcephaly-affected Pakistani families were located and identified from February 2017 to May 2019 and were selected for participating in this research. The study was approved by the ethics committee of the University of the Punjab, Lahore Pakistan. A complete family history was obtained from the guardians of these families. For clinical assessment, all patients were examined by genetic consultants and medical experts. Consanguineous sib ship was confirmed through multiple interviews. Relevant information for these families was gathered by completing questionnaires.

\subsection{Sample Collection and Extraction}

Peripheral blood samples were collected in EDTA vacutainers from all family members, including parents, normal siblings, and affected individuals. DNA extraction was done in University of the Punjab, by using the salting-out method (Helms, 1990) using Falcon $50 \mathrm{ml}$ tubes. DNA quality and quantity were estimated by spectrophotometry (Nanodrop method) and 1\% Agarose gel electrophoresis, respectively. For DNA staining, fluorescent dye ethidium bromide was used. Bands of DNA were visualized on a UV gel transilluminator documentation system (imaging system by SynGene).

\subsection{Mutation Detection Using Whole-Exome Sequencing}

Whole-exome sequencing is a powerful diagnostic tool for evaluation of highly heterogeneous neurodevelopmental disorders. Whole-exome sequencing (WES) in affected individuals (V-3 of Family A; V-1 of Family B; IV-1 of Family C) from the affected Pakistani families was performed in the Cologne Center for Genomics, University of Cologne by using the Agilent (Santa Clara, CA) version 6 enrichment kit and the Illumina HiSeq 4000 sequencing system (paired-end reads, 2375 bp). The experimental procedure and data handling were performed as reported previously (Hussain et al., 2012; Hussain et al., 2013). The VARBANK database (http:// varbank.ccg.uni-koeln. de) and analysis tool kit were used for the filtration and prioritization of variants (Szczepanski et al., 2016).

\subsection{Sanger Sequencing}

Sanger sequencing was performed to confirm the pathogenic mutation discovered by WES. The Ensemble genome browser (http://asia.ensembl.org/index.html) was used to download the $10877 \mathrm{bp}$ genomic sequence of the ASPM gene (ENST00000367409.8). The following primers were designed using the primer3 software (http://frodo. wi.mit.edu/primer3/): F5'-TTCCAAAGATGAACACAAGAAG-3' and R5'-ACCATAACGAGCTTTTCAGG-3' for exon 17, and F5 $^{\prime}$-GATGTAGATATAAATAGAAAACATTGG- $3^{\prime}$ and R5'-CAGGGGCATATTTTGTTGAC-3' for exon 24. The PCR products were sequenced bidirectionally using a Big Dye Terminator v1.1 cycle sequencing kit on an ABI3730xl 
automated DNA Sequencer. Sequences were analyzed with DNASTAR (Lasergene) and Mutation Surveyor (Soft Genetics).

\section{Results}

Consanguineous Pakistani families with inherited autosomal recessive primary microcephaly with at least two living affected members born to phenotypically normal parents were recruited for this study. Photographs of affected members and pedigrees of these affected families were constructed and are represented in Figure 1. Clinical information of the MCPH patients was described, including their head circumference (Standard deviation), age, sex,
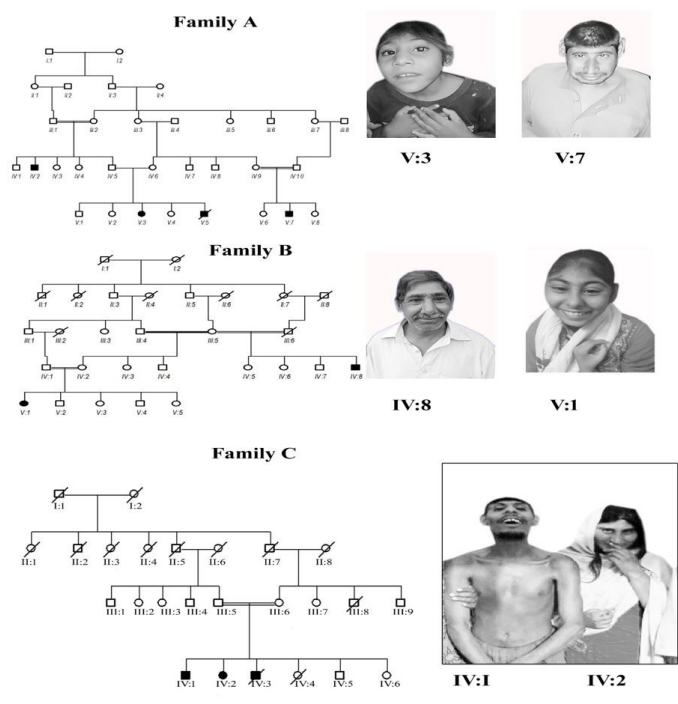

Figure 1. Pedigrees and photographs of affected members of MCPH families with sloping forehead and variable head circumference. Squares represent males while circles represent females; the shaded symbols are for affected individuals, while the double line between individuals represents consanguinity. age at which they started walking, mental retardation, severity in behavior, and the presence of any other disorders, such as epilepsy and speech delay in Table 1. Parents in these families showed normal intelligence scores and normal head circumference. A novel homozygous deletion mutation c.3877_3880del GAGA was detected in exon 17 of the ASPM gene in two Pakistani families (A and B) with MCPH. Electropherograms of exon 17 for the ASPM gene showed the variation c.3877_3880delGAGA in $\mathrm{V}: 3$ and $\mathrm{V}: 1$, represented in upper traces of family $\mathrm{A}$ and B, respectively. Electropherograms IV: 5 and IV: 2 represented carriers (parents) of family $A$ and $B$ in medium traces. Electropherograms of wild type DNA represented in lower traces. Black arrows indicate the position of the mutations (Figure 2a). Sanger electropherograms of exon 24 for the ASPM gene showed the variation c.9730C $>\mathrm{T}$ in IV: 1 affected sibling of family $C$ and wild type DNA. Black arrows indicated the position of the mutation (Figure $2 \mathrm{~b}$ ).

\section{Discussion}

The ASPM protein is essential for normal mitotic spindle function in embryonic neuroblasts. By promoting the division of neural progenitor cells during early brain development, ASPM gene helps to determine the total number of neurons and overall brain size (Geoffrey et al., 2005). Defects in the ASPM protein are associated with autosomal recessive microcephaly and mild to severe mental retardation (Hashmi et al., 2016). The ASPM gene mutation c.3877_3880delGAGA, which truncates the protein (p. Glu1293Lysfs*10) and causes a loss of the calmodulin-binding IQ domain and Armadillo-like domain of the ASPM protein, was detected in exon 17 in two Pakistani families (A and B) with MCPH (Figure 3a). Spindle formation during cell division, which is regulated by calmodulin, is associated with the IQ motif of the ASPM protein. During interphase, calmodulin is in the cytoplasm and is associated with mitotic spindles during mitosis. Inhibition of cytokinesis and abnormal spindle formation takes place due to mutations in the calmodulin-binding

Table 1. Clinical information of the MCPH patients included in this study.

\begin{tabular}{|c|c|c|c|c|c|c|c|}
\hline Family ID & $\begin{array}{l}\text { Patient } \\
\text { ID sex }\end{array}$ & $\begin{array}{l}\text { Age } \\
\text { (year) }\end{array}$ & $\begin{array}{l}\text { OFC } \\
\text { (SD) }\end{array}$ & $\begin{array}{l}\text { Mental } \\
\text { retardation }\end{array}$ & $\begin{array}{c}\text { Age at } \\
\text { walking } \\
\text { years }\end{array}$ & Behavior Pattern & Others anomaly \\
\hline \multirow[t]{2}{*}{ A } & IV:2 (M) & 22 & -9.4 .0 & Severe & 10 & Very aggressive & $\begin{array}{c}\text { Epilepsy, reduced } \\
\text { height, speech } \\
\text { delay }\end{array}$ \\
\hline & $\mathrm{V}: 3(\mathrm{~F})$ & 7 & -12.0 & Moderate & 2 & Friendly & $\begin{array}{l}\text { Speech delay, hear } \\
\text { impairment }\end{array}$ \\
\hline \multirow[t]{2}{*}{ B } & $\mathrm{V}: 1(\mathrm{~F})$ & 17 & -8.9 & Moderate & 2 & $\begin{array}{l}\text { Friendly, active, } \\
\text { school going }\end{array}$ & $\begin{array}{l}\text { Hormonal } \\
\text { Disturbance }\end{array}$ \\
\hline & IV:8 (M) & 48 & -8.9 & Moderate & 3 & Friendly and active & $\begin{array}{l}\text { reduced height, } \\
\text { speech delay }\end{array}$ \\
\hline \multirow[t]{2}{*}{ C } & $1 \mathrm{~V}: 1(\mathrm{M})$ & & -9.7 & Severe & 3 & Violently react & $\begin{array}{l}\text { Seizures, general } \\
\text { weakness }\end{array}$ \\
\hline & $1 \mathrm{~V}: 2(\mathrm{~F})$ & 22 & -6.3 & Severe & 2 & Aggressively & Speech delay \\
\hline
\end{tabular}


Family A
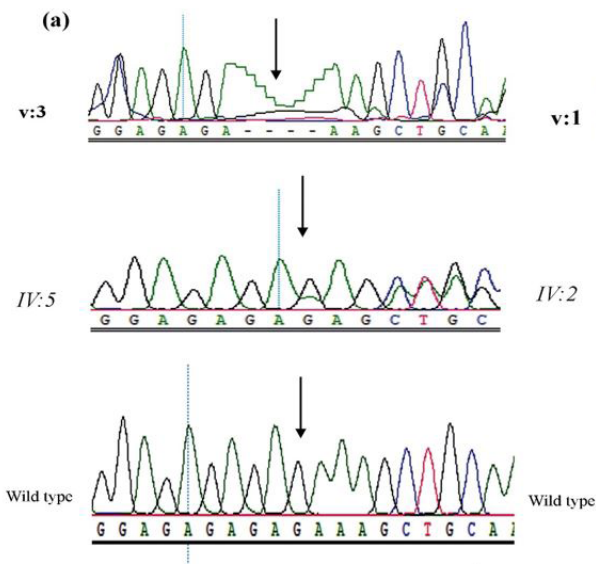

Family C

\author{
(b)
}

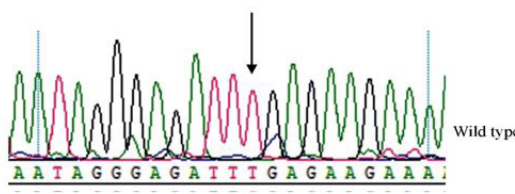

Family B

v: 1

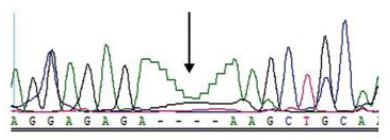

$I V: 2$
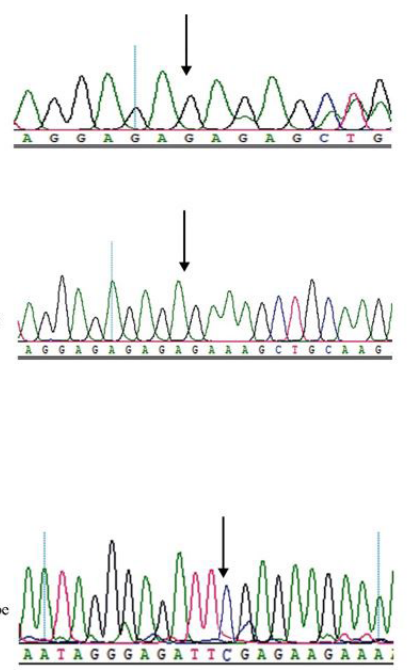

Figure 2. a) Electropherogram of novel mutation in exon 17 of the ASPM gene; homozygous deletion mutation c.3877_3880delGAGA of microcephaly affected individual in Family A and B. b) Reported mutation of exon 24 (c.9730C $>$ T) of the ASPM gene of microcephaly affected individual in Family C

a)

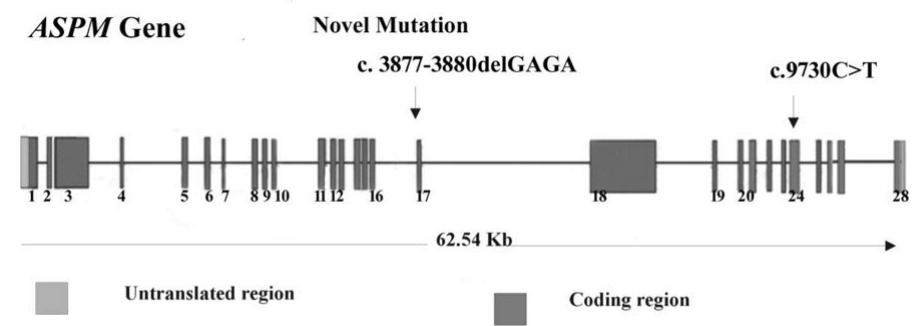

b)

ASPM Protein

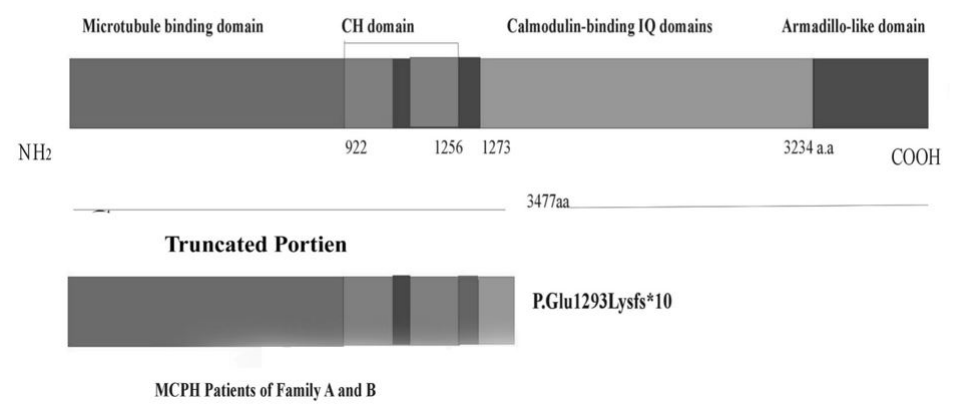

Figure 3. (a) ASPM gene structure with 28 exons, Novel mutation identified in exon 17 in Family A and Family B; previously reported mutation finding in exon 24 in Family C. (b) ASPM gene codes for the 3477-amino acid protein with four protein domains; the nonsense mutation p. Glu1293Lysfs* 10 in patients from families A and B leads to a truncated protein that is missing a large part of the calmodulin-binding IQ domain and the Armadillo-like domain of ASPM protein. 
Table 2. Pathogenicity score of novel mutations detected using in silico tools.

\begin{tabular}{ccc}
\hline S. No & Online tools & Pathogenicity score \\
\hline 1 & MutationTaster (http://www Mutationtaster.org/) & Disease Causing \\
2 & Polyphen-2 “http://genetics” Bwh.harvard.edu/pph2/) & $\mathbf{0 . 0 1 0}$ (sensitivity: 0.96; specificity: 0.77) \\
3 & PROVEAN & 6.910 Deleterious \\
4 & MUTATION ASSESSOR (http://mutationassessor.org) & 1.04 F Functional impact low \\
\hline
\end{tabular}

Table 3. Gene (exon), Ref. Seq. ID, cDNA mutations, amino acid changes, Genome AD frequency and family ID are elaborated for novel and reported mutations.

\begin{tabular}{ccccccc}
\hline $\begin{array}{c}\text { Gene } \\
\text { (Exon) }\end{array}$ & Ref. Seq. ID & cDNA mutation & $\begin{array}{c}\text { Amino acid } \\
\text { change }\end{array}$ & $\begin{array}{c}\text { GnomAD } \\
\text { Frequency }\end{array}$ & $\begin{array}{c}\text { Family } \\
\text { ID }\end{array}$ & Reference \\
\hline ASPM 17 & $\begin{array}{l}\text { NM_018136.4 } \\
\text { "http://www. } \\
\text { ncbi.nlm.nih. } \\
\text { gov/nuccore }\end{array}$ & c.3877_3880delGAGA & p. Glu1293Lysfs*10 & 0.000004000 & A & Novel mutation \\
ASPM 17 & $\begin{array}{l}\text { NM_018136.4 } \\
\text { "http://www. } \\
\text { ncbi.nlm.nih. } \\
\text { gov/nuccore }\end{array}$ & c.3877_3880delGAGA & p. Glu1293Lysfs*10 & 0.000004000 & B & Novel mutation \\
NMPPM 24 & c18136.4 & c.9730C>T & p. Arg3244* & 0.000003990 & C & Reported \\
\hline
\end{tabular}

IQ domain of the ASPM protein (Khan et al., 2017; Willingham et al., 1983). Novelty of this mutation in the Pakistani population also confirmed by visiting https:// pakmutation.kust.edu.pk/. The pathogenic effect of this novel mutation was tested using in silico tools, including MutationTaster, PolyPhen, and PROVEAN; the mutation was predicted to be "disease causing," characterized by high pathogenicity scores while for functional impact used Mutation Assessor elaborated in Table 2. Deletion of glutamic acid causes a frameshift mutation in the ASPM protein (p. Glu1293Lysfs*10), leading to protein truncation due to premature stop codon; untranslated calmodulin-binding IQ and armadillo-binding domains (Figure 3b). Genome AD frequency, Ref. Seq. ID, cDNA mutation, and amino acid change are elaborated (Table 3 ). We also identified one previously reported mutation (c.9730C $>$ T) in the 24th exon of the ASPM gene in one family (family C) showing clinical signs of primary microcephaly (Welsh et al., 1979). The MCPH5 locus shows varied incidence in different ethnic populations. For instance, this rate is in the range of $43-86 \%$ in the Pakistani population, $33.5 \%$ in the Indian population, and $13.3 \%$ in the Iranian population (Darvish et al., 2010; Nicholas et al., 2009; Paramasivam et al., 2007).

\section{Conclusion}

The ASPM gene (MCPH5) occupies the most prominent locus in the disease etiology of primary microcephaly, owing to its mutation rate which is as high as 50 to $90 \%$. Deletion of glutamic acid causing frameshift mutation, insertion of premature stop codon leading to protein truncation and untranslated calmodulin-binding IQ and armadillo-binding domains involved in cytokinesis and spindle formation. ASPM is very crucial gene involve in brain functioning and determine the size of brain. Identification of this novel mutation has increased the mutational spectra of ASPM gene, but further functional exploration is required to develop a phenotype genotype correlation.

\section{Acknowledgements}

We would like to acknowledge Dr. Shahid Baig(Director, Health Division, NIBGE), Prof. Dr. Peter Nüernberg, and Dr. Muhammad Sajid Hussain from the Cologne Center for Genomics, University of Cologne, for whole-exome mapping. We extend our gratitude to all the members of the affected families included in this study, for their cooperation and voluntary participation.

\section{Reference}

BIBI, R., MAQBOOL, A., KHAN, S. and KHAN, J., 2018. Microcephaly-A Neurodevelopment Hereditary Disorder with emerging drift of Zikv. Fuuast J BIOL, vol. 8, no. 1, pp. 123-132.

BOND, J., ROBERTS, E., MOCHIDA, G.H., HAMPSHIRE, D.J., SCOTT, S., ASKHAM, J.M., SPRINGELL, K., MAHADEVAN, M., CROW, Y.J., MARKHAM, A.F., WALSH, C.A. and WOODS, C.G., 2002. ASPM is a major determinant of cerebral cortical size. Nature Genetics, vol. 32, no. 2, pp. 316-320. http://dx.doi.org/10.1038/ng995. PMid: 12355089.

BUNDEY, S., 1997. Prevalence and type of cerebral palsy. Developmental Medicine and Child Neurology, vol. 39, no. 8, pp. 568. http://dx.doi.org/10.1111/j.1469-8749.1997.tb07489.x. PMid:9295856. 
DARVISH, H., ESMAEELI-NIEH, S., MONAJEMI, G.B., MOHSENI, M., GHASEMI-FIROUZABADI, S., ABEDINI, S.S., BAHMAN, I., JAMALI, P., AZIMI, S., MOJAHEDI, F., DEHGHAN, A., SHAFEGHATI, Y., JANKHAH, A., FALAH, M., SOLTANI BANAVANDI, M.J., GHANI, M., GARSHASBI, M., RAKHSHANI, F., NAGHAVI, A., TZSCHACH, A., NEITZEL, H., ROPERS, H.H., KUSS, A.W., BEHJATI, F., KAHRIZI, K. and NAJMABADI, H., 2010. A clinical and molecular genetic study of 112 Iranian families with primary microcephaly. Journal of Medical Genetics, vol. 47, no. 12, pp. 823-828. http://dx.doi. org/10.1136/jmg.2009.076398. PMid:20978018.

GEOFFREY, W.,JACQUELYN, B. and WOLFGANG, E., 2005. Autosomal Recessive Primary Microcephaly (MCPH): A Review of clinical molecular and evolutionary findings. American Journal of Human Genetics, vol. 76, no. 5, pp. 717-728. http://dx.doi. org/10.1086/429930. PMid:15806441.

HASHMI, J.A., AL-HARBI, K.M., RAMZAN, K., ALBALAWI, A.M., MEHMOOD, A., SAMMAN, M.I. and BASIT, S, 2016. A novel splice-site mutation in the ASPM gene underlies autosomal recessive primary microcephaly. Annals of Saudi Medicine, vol. 36, no. 6, pp. 391-396. http://dx.doi.org/10.5144/02564947.2016.391. PMid:27920410.

HELMS, C. Salting out Procedure for Human DNA extraction. The Donis-Keller Lab-Lab Manual Homepage, 1990.

HINA, M., ABDUL, S., AYESHA, H.S. and WASIM, A., 2019. Mutation analysis of ASPM gene in two Pakistani Families with autosomal recessive primary microcephaly. IJB, vol. 14 , no. 3, pp. 503-507. http://dx.doi.org/10.12692/ijb/14.3.503-507.

HUSSAIN, M.S., BAIG, S.M., NEUMANN, S., NÜRNBERG, G., FAROOQ M., AHMAD, I., ALEF, T., HENNIES, H.C., TECHNAU, M., ALTMÜLLER, J., FROMMOLT, P., THIELE, H., NOEGEL, A.A. and NÜRNBERG, P., 2012. A truncating mutation of CEP135 causes primary microcephaly and disturbed centrosomal function. American Journal of Human Genetics, vol. 90, no. 5, pp. 871-878. http:// dx.doi.org/10.1016/j.ajhg.2012.03.016. PMid:22521416.

HUSSAIN, M.S., BAIG, S.M., NEUMANN, S., PECHE, V.S., SZCZEPANSKI, S., NÜRNBERG, G., TARIQ M., JAMEEL, M., KHAN, T.N., FATIMA, A., MALIK, N.A., AHMAD, I., ALTMÜLLER, J., FROMMOLT, P., THIELE, H., HÖHNE, W., YIGIT, G., WOLLNIK, B., NEUBAUER, B.A., NÜRNBERG, P. and NOEGEL, A.A., 2013. CDK6 associates with the centrosome during mitosis and is mutated in a large Pakistani family with primary microcephaly. Human Molecular Genetics, vol. 22, no. 25, pp. 5199-5214. http://dx.doi.org/10.1093/ hmg/ddt374. PMid:23918663.

JAYARAMAN, D., BAE, B.-I. and WALSH, C.A, 2018. Genetics of Primary Microcephaly. Annual Review of Genomics and Human Genetics, vol. 19, no. 1, pp. 177-200. http://dx.doi.org/10.1146/ annurev-genom-083117-021441. PMid:29799801.

KHAN, M.A., WINDPASSINGER, C., ALI, M.Z., ZUBAIR, M., GUL, H., ABBAS, S., KHAN, S., BADAR, M., MOHAMMAD, R.M. and NAWAZ Z., 2017. Molecular genetic analysis of consanguineous families with primary microcephaly identified pathogenic variants in the ASPM gene. Journal of Genetics, vol. 96, pp. 383-387. https:// doi.org/10.1007/s12041-017-0759-X.

LI, C., XU, D., YE, Q., HONG, S., JIANG, Y., LIU, X., ZHANG, N., SHI, L., QIN, C.F. and XU, Z., 2016. Zika virus disrupts neural progenitor development and leads to microcephaly in mice. Cell Stem Cell, vol. 19, no. 1, pp. 120-126. http://dx.doi.org/10.1016/j. stem.2016.04.017. PMid:27179424.

NAVEED, M., KAZMI, S.K., AMIN, M., ASIF, Z., ISLAM, U., SHAHID, K. and TEHREEM, S., 2018. Comprehensive review on the molecular genetics of autosomal recessive primary microcephaly. Genetical Research, vol. 100, no. 7, pp. 1-16. http://dx.doi.org/10.1017/ S0016672318000046. PMid:30086807.

NICHOLAS, A.K., SWANSON, E.A., COX, J.J., KARBANI, G., MALIK, S., SPRINGELL, K., HAMPSHIRE, D., AHMED, M., BOND, J., DI BENEDETTO, D., FICHERA, M., ROMANO, C., DOBYNS, W.B. and WOODS, C.G., 2009. Molecular landscape of ASPM mutations in primary microcephaly. Journal of Medical Genetics, vol. 46, no. 4, pp. 249-253. http://dx.doi.org/10.1136/jmg.2008.062380. PMid:19028728.

PARAMASIVAM, M., CHANG, Y.J. and LO-TURCOU, J.J., 2007. ASPM and citron kinase co-localize to the midbody ring during cytokinesis. Cell Cycle (Georgetown, Tex.), vol. 6, no. 13, pp. 16051612. http://dx.doi.org/10.4161/cc.6.13.4356. PMid:17534152.

PEREZ, Y., BAR-YAACOV, R., KADIR, R., WORMSER, O., SHELEF, I., BIRK, O.S., FLUSSER, H. and BIRNBAUM, R.Y, 2019. Mutations in the microtubule-associated protein MAP11 (C7orf43) cause microcephaly in humans and zebrafish. Brain, vol. 142, no. 3, pp. 574-58. http://dx.doi.org/10.1093/brain/awz004. PMid:30715179.

ROBERTS, E., HAMPSHIRE, D.J., PATTISON, L., SPRINGELL, K., JAFRI, H., CORRY, P., MANNON, J., RASHID, Y., CROW, Y., BOND, J. and WOODS, C.G., 2002. Autosomal recessive primary microcephaly: an analysis of locus heterogeneity and phenotypic variation. Journal of Medical Genetics, vol. 39, no. 10, pp. 718-721. http:// dx.doi.org/10.1136/jmg.39.10.718. PMid:12362027.

SZCZEPANSKI, S., HUSSAIN, M.S., SUR, I., ALTMÜLLER, J., THIELE, H., ABDULLAH, U., WASEEM, S.S., MOAWIA, A., NÜRNBERG, G., NOEGEL, A.A., BAIG, S.M. and NÜRNBERG, P., 2016. A novel homozygous splicing mutation of CASC5 causes primary microcephaly in a large Pakistani family. Human Genetics, vol. 135, no. 2, pp. 157-170. http://dx.doi.org/10.1007/s00439-0151619-5. PMid:26621532.

THORNTON, G.K. and WOODS, C.G., 2009. Primary microcephaly do all roads lead to Rome. Trends in Genetics, vol. 25, no. 11, pp. 501-510. http://dx.doi.org/10.1016/j.tig.2009.09.011. PMid: 19850369.

TISCHFIELD, M.A., CEDERQUIST, G.Y., GUPTA, M.L. Jr. and ENGLE, E.C., 2011. Phenotypic spectrum of the tubulin related disorders and functional implications of disease-causing mutations. Current Opinion in Genetics \& Development, vol. 21, no. 3, pp. 286-294. http://dx.doi.org/10.1016/j.gde.2011.01.003. PMid:21292473.

WELSH, M.J., DEDMAN, J.R., BRINKLEY, B.R. and MEANS, A.R., 1979. Effects of microtubule and microfilament inhibitors on localization in the mitotic apparatus. The Journal of Cell Biology, vol. 81, no. 3, pp. 624-634. http://dx.doi.org/10.1083/ jcb.81.3.624. PMid:379022.

WILLINGHAM, M.C., WEHLAND, J., KLEE, C.B., RICHERT, N.D., RUTHERFORD, A.V. and PASTAN, I.H., 1983. Ultrastructural immunocytochemical localization of calmodulin in cultured cells. The Journal of Histochemistry and Cytochemistry, vol. 31, no. 4, pp. 445-461. http://dx.doi.org/10.1177/31.4.6338107. PMid:6338107.

WOLLNIK, B.A., 2010. Common mechanism for microcephaly. Nature Genetics, vol. 42, no. 11, pp. 923-924. http://dx.doi.org/10.1038/ ng1110-923. PMid:20980985.

WOODS, C.G. and PARKER, A., 2013. Investigating microcephaly. Archives of Disease in Childhood, vol. 98, no. 9, pp. 707-713. http:// dx.doi.org/10.1136/archdischild-2012-302882. PMid:23814088. 